\title{
The Changing Pattern of Classes and Class Conflict in China
}

Alvin Y. So*

China's development since the reform era has presented several puzzles to researchers in the China field. First, there is the puzzle of cyclical reform. Unlike the "big bang" reform in Eastern Europe, China's economic reforms take the shape of "two steps forward, one step backward," with a few years of reform wave followed by a couple of years of economic retrenchment. Zhu Rongji's reform offensive in 1998, for example, was stalled in 2000 (Zweig, 2001). How then could we explain this pattern of cyclical reform despite many top leaders in the Chinese Communist Party (CCP) who are determined to implement economic reforms?

Second, there is the puzzle of the lack of impetus toward democratization. The assumption in the literature is that rapid economic development will lead to the expansion of the private sector, the expansion of a cosmopolitan middle class, the strengthening of civil society, and the transition from authoritarianism to democracy in post-reform China (Pearson, 1998; Howell, 1998). Nevertheless, despite China's robust economic development over the past two decades, and despite the rigorous democracy movement at the Tiananmen Square in 1989, there have been little signs of a democratic breakthrough in China since the late 1980s. What then explains the persistence of a non-democratic institution in China despite its robust economic development?

Third, there is the puzzle of a pacified working class in China. When the entitlements of workers (such as welfare, job security, pension, health care, etc.) are threatened, workers generally respond through protests, demonstrations, and strikes in order to protect their privileges. However, despite the economic reforms that have led to massive layoffs of Chinese workers and to cutting back of their entitlements, Chinese workers have yet to form a labor movement to challenge the economic reforms and the Chinese government. What then explains the lack of working class struggle in Chinese society?

This article argues that the above puzzles could best be understood through examining the interaction of three factors: the state, economic reforms, and classes in postreform China. In the literature on China's development, the focus has been on the state and economic reforms and very little study has been on classes. The aim of this article is to bring classes and class conflict back in so as to explain the puzzles of cyclical reform, stalled democratization, and a pacified working class in China.

*Division of Social Science, University of Science and Technology, Clcar Water Bay, Hong Kong

Journal of Comtemporaty Asia, Vol. $33 \mathrm{No} .3$ (2003) 
It is ironic that when the economic foundation of classes was dissolved and the intensity of class conflict was much reduced during the socialist transformation in the 1950 s and the 1960s, the Maoists used the outdated terms "classes" and "class struggles" all the time in their political campaigns. On the other hand, although the post-1978 economic reforms have reconstructed the economic foundation of classes and class conflict has been greatly intensified, there is little effort to analyze the present Chinese society from a class analysis viewpoint.

Instead of class analysis, the literature offers a stratification analysis of the impact of marketization on Chinese society. The debate between the "market transition" theorists and the so-called "state-centered" theorists is on whether the power of state managers has been eroded by market forces, whether inequalities have been increased in the market transition after 1978, and whether human capital, social network, entrepreneurship, and the local state have induced new forms of inequality as economic reforms progressed. This market transition debate has clarified our understanding of the intricate linkages between market, inequalities, and social strata in the post-reform era, and has made a significant contribution to the literature of social stratification and Chinese society (Nee, 1989, 1996; Parish and Michelson, 1996; Walder, 1996).

Nevertheless, except for a couple of researchers, the literature on socialist market transition has so far avoided raising the issues of classes in its analysis. This negligence of class analysis in the China field is unfortunate because class analysis has proved to be an important method in historical and comparative sociology. The works of E.P. Thompson, Barrington Moore, Theda Skocpol, Erik Wright, and Michael Burawoy have used class analysis to make sense of the origins of democracy and dictatorship, revolutions, and socialist transformation to capitalism in Eastern Europe.

Using a historical class analysis, this article wants to study the following research questions: What was the pattern of classes and class conflict in the Maoist era (19491978)? After the Chinese state replaced the Maoist project with the Four Modernizations, what new patterns of classes and class relationship have emerged since 1978 ? In what ways have such patterns of class relationship affected reform policies, democratization, and working class conflict?

This article argues that the state has played a decisive role in the shaping of class relations in the Maoist era, resulting in a statist society. Although new classes and new class relationship have emerged from the economic reforms, the Chinese state has continued to play a decisive role to reconstruct the contour of class formation and class conflict, leading to the birth of a state-mediated class-divided society since 1978. In order to understand why and how such profound transformation took place, the following section will provide a brief historical review on the nature of the statist society in the Maoist era.

\section{The Emergence of a Statist Society During 1949-1978}

Before the Communist Revolution in 1949, China had a weak state but a strong classdivided seciety. In the first half of the twentieth century, the breaking up of the imperial state into warlord regions, the incorporation of China into the capitalist world-economy, the march toward capitalist industrialization, and the two World Wars had generated 
new forms of class conflict in Chinese society. In the countryside, as scholar-gentry gave way to "evil gentry" and local bullies, landless poor peasants formed peasant associations and waged in a survival struggle against landlords and rich peasants. In the urban areas, as China started the first wave of industrialization, the nascent working class formed unions, organized strikes, and waged bread-and-butter struggles with both foreign and Chinese capitalists. The new middle class intellectuals at first promoted the path of reforms and democracy, but they were soon pushed to the side of peasants and workers as class conflict intensified. Of course, class conflict, by itself, is insufficient to start a revolution. However, class conflict had laid the foundation of the communist revolution when the Chinese Communist Party (CCP) seized this golden opportunity to wage political struggles against the ruling Guomindang government, the Japanese invaders, and the Chinese landlords during World War II.

A totally new statist society emerged after the 1949 Communist Revolution. The CCP built up an all-powerful Leninist-state that had the capacity to impose state policies onto the Chinese society. In addition, the CCP carried out a socialist project to eliminate the economic foundation of classes, so societal forces could be directly under the control of the state. The hostility from the U.S. during the Cold War, the forced withdrawal from the capitalist world-economy, and the constant threat of counter-revolutionaries had made the CCP determined to create a new statist/classless society.

Thus, the CCP used the land reform program to dissolve the economic foundation of the landlord class, the collectivization program to dissolve the economic foundation of the rich peasant class, the nationalization program to dissolve the economic foundation of the capitalist class, the Hundred Flower Campaign to dissolve the economic foundation of the new middle class intellectuals, and the Cultural Revolution to increase its control over the new middle class intellectuals and the state managers. After the implementation of these policies, the economic foundations of classes were largely eroded and conflict between classes lost it prominence. As a result, the Chinese society was transformed from a class-divided society to a statist society ruled by a strong Leninist party-state.

In the statist society, the party-state monopolized the economic, political, and social resources in the society. Workers and peasants were completely dependent on the state not only for job and income but also for services, status, and influence in the community. The formation of a statist society exerted a profound impact on state-society relations. When class (and other political) organizations were either eliminated or absorbed in the state structure, there was no intermediation between the state and society. The state could directly control society and impose its policies on the society.

Thus, the common features of this statist society are the politicization of social/ economic issues, the constant mobilization of individuals, and rupture conflict (the sudden rise and fall of highly intensive and violent conflict). In this statist society, the contour of conflict had shifted from class conflict to conflict between the state and individuals. It is, therefore, ironic that even when the objective economic bases of antagonistic classes were eroded, the subjective categories "class" and "class struggles" were used all the time by the Maoists in their political campaigns. 


\section{Economic Reforms and the Reemergence of Classes Since 1978}

However, since the Maoists focused on "class struggles" and political campaigns, they had neglected to promote economic development. When cconomic output and productivity in the 1970s could no longer be increased through political mobilization, there was a calling for a "Four Modernization" program to jump start the Chinese economy. Subsequently, when the old generation of Maoist revolutionarics passed away, and when the U.S. lowered its hostility and welcomed China back to the capitalist world-economy, the so-called reformers recreated a mixed (state, collective, and private) economy, laying the economic foundation of classes and class conflict in the post-1978 reform era.

The China Studies literature tends to label this period as the era of market transition. However, although marketization is a very important process in this period, one also shouldn't overlook the profound transformation in the production sphere, ownership relations, and the reemergence of classes and class conflict. Reintegration into the capitalist world-economy has laid the economic foundation for the recreation of a foreign capitalist class engaging either in sole ownership or in joint ventures with Chinese enterprises. Decollectivization has recreated a rich peasant class that capitalized on the abundant supply of surplus laborers in the countryside. The expansion of the private sector has given rise to an old middle class (petty-bourgeoisie getihu employing less than 10 workers) and to a capitalist class (entrepreneurs employing 10 workers or more). Decentralization, enterprise reforms, and the success of township enterprises have greatly expanded the size of the new middle class (corporate professionals such as mid-level managers and accountants). The expansion of higher education institutions and the service sector has greatly expanded the size of another segment of the new middle class (service professionals such as teachers and journalists). The recreation of the labor market means that the working class now needs to sell its labor to the market for a living. Loosening the household registration system has induced peasants to go to nearby market towns or faraway urban cities to work as temporary migrant workers, creating a new wave of the proletarianization of the peasantry.

After the reconstruction of the economic foundations of the above classes, a classdivided society quickly emerged in China. First, there was a rapid class differentiation in both the countryside and the city. In the countryside, a relatively homogeneous peasant stratum in the Maoist era was now been split into a rich peasant class and a poor peasant class. No longer able to earn a living on their tiny family farms, many poor peasants have to work for rich peasants as laborers in their farms or as workers in their village enterprises. In the cities, a relatively homogeneous urbanite is now split into a capitalist class, an old middle class of self-employed and small employer, and a working class subdivided into permanent urban workers and temporary migrant workers. In the private and collective enterprises, temporary migrants worked in a capitalist situation not too much different from their counterparts in the early stage of the Industrial Revolution. They had to work very long hours, get only minimum wages, obey strict work disciplines, get hired on a day-to-day basis, and were unable to form labor unions to protect their interests. Studies have shown that the capitalist class frequently invokes the factors of gender (like paying female workers less than male workers), ethnicity (like hiring out-of-province migrant workers than local workers), and kinship ties (like recruiting workers from the same vil- 
lage as that of the foreman) in order to lacilitate its control over the workers (Lee, 1998; Pun, 2001).

Second, aside from class differentiation, there has also been a growing trend of class polarization. Many studies show that the rich are getting richer and the poor are getting poorer. At the top there are millionaires and even billionaires. At the bottom there is an underclass of temporary migrants in the city and poverty is widespread in inland provinces. In the early 1980s, China was among the world's most egalitarian societies. By the mid-1990s, the inequalities of income distribution in China not only already excceded the inequality found in the transition economies in Eastern Europe and the high-income countries of Western Europe and North America, but also those in China's Asian neighbors such as India, Pakistan, and Indonesia (Wang and Hu, 1999).

Third, conflict has begun to take the form of class conflict, organizing along class line, and raising class issues. In the countryside, there are many rural protests from poor peasants complaining about high taxes, irregular taxes, low prices of their agricultural products, encroachment of their land and house, the state's IOUs, etc. In the city, there are many protests from workers complaining about their layoffs, the closing down of their enterprises, the reduction of their wages and benefits, the abuses by their managers, etc. In 1989, workers joined hands with the middle class students, intellectuals, and capitalists to wage a robust democracy movement complaining of corruption, high rates of inflation, and the lack of independent unions (Lau, 1997; Lee, 2000; Pei, 2000; Perry and Selden, 2000). In May 2001, a report issued by a Central Committee research group spoke of "tense" relations between the party and the people. The report spoke about the collapse of state-owned industry, a social safety net incapable of dealing with millions of unemployed, strained relations with China's ethnic minorities, a restive peasantry and an unjust legal system (Pomfret, 2001).

Despite the above processes of class differentiation, class polarization, and class conflict, however, the class-divided society that reemerged since 1978 is different from its predecessor in the first half of the twentieth century. Pre-1949 China was a class-divided society embedded in a weak state. Thus, social classes and class conflict had a much larger role to play in the promotion of political change and societal transformation. Post-1978 China, however, is a class-divided society embedded in a strong Leninist party-state, thus social classes and class conflict are mediated through the state and shaped by the state.

What then is the new pattern of class and class conflict in the state-mediated classdivided society? The following sections will examine the transformation in state-capitalist relations state-workers relations, state-new middle class relations, state-peasants relations, and the institutionalization of class conflict through state corporatism.

\section{State-Capitalist Relations}

The Embourgeoisiement of Cadres: The capitalist class reemerged in the post-1978 reform era is stamped with the trademark of the statist society. Since the old Chinese capitalist class was eliminated in the 1950s, a new class of capitalist entrepreneurs had to be created in order to promote marketization reforms. Therefore, on the one hand, there is the embourgeoisiement of cadres. During the first decade of the economic re- 
forms which aimed to create a private sector, cadres turned the local state and collective enterprises into profitable township enterprises (local state corporatism), developed joint ventures with foreign capitalists and overseas Chinese capitalists, quit their official positions and set up their own capitalist enterprises, and hired their kin and friends to run them. Since cadres possessed political capital as well as the necessary networks to run their enterprises, they had an edge over other classes in taking advantage of the nascent business opportunities in the first decade of the reform era (Goodman, 1996).

During the second stage of reform in the 1990s, when the state called for the privatization of state enterprises (through shareholdings) and "Grasp the big, release the small," there was a massive diversion of the assets and profits of state enterprises into the private hands of the cadres in charge of them (Huchet, 2000; Duckett, 2001). Ding's (2000a, 2000b) studies point to the following three ways that state enterprises can be stripped off: Organizational proliferation, consortium-building, and "one manager, two businesses." In Organizational proliferation, cadres stripped off its best equipped or most profitable segments and turned these into new collective-owned companies. Consortium-Building refers to a partnership between PRC bodies in which a state-owned enterprise sets up a new firm in collaboration with a non-state-owned enterprise. "One manager, two businesses" happens when cadres established their own private business by usurping assets from the state industries in which they hold executive positions. Francis (2001, p.285) points out that these practices are carried out by all sorts of state entities "local and municipal governments, national ministries, the army, national and local public security bureaus, party organizations, universities, scientific institutes." The coexistence and inter-penetration of various forms of ownerships between the state and the nonstate domain have provided a golden opportunity for cadres to transform themselves into capitalist owners and managers of semi-state, collective, and private properties.

The Patronization of Capitalists: On the other hand, there is the patronization of the capitalist class. The nascent mainland capitalists, as well as the overseas Chinese capitalists from Hong Kong and Taiwan, were still too weak to challenge the outdated bureaucratic rules and regulations, corruption, and irregular taxes. Instead of trying to transform the state bureaucracy or pushing for a more transparent regulatory system, most capitalists preferred to work within the existing structure.

What the capitalists needed was to find a cadre patron to provide them with vital information, to get access to credit, raw materials, and market, and to shield them from arbitrary and irregular taxes. The support of a patron can also enable the capitalists to avoid the labor regulations that apply in the state sector, so as to save on the additional costs of pension schemes, health and welfare insurance, environmental protection facilities. As a result, partnership with cadres and transforming their property into collective enterprises (usually called "wearing the red hat") is the necessary step if capitalists want to upgrade, enlarge, and secure their enterprises. In order to gain the support of their patrons, capitalists mobilized social networks, kinship ties, and overseas connections, provided material and symbolic gifts, processing fees, and even offered shares and partial ownership to cadres. In return, cadre patrons favored their clientele capital- 
ists over other non-clientele capitalists (Goodman, 2000; Wu, 2001).

The latest development in the patronization is to allow capitalists to be recruited into the communist party. In a speech marking CCP's $80^{\text {th }}$ anniversary on July 1, 2001, General Secretary Jiang Zemin urged the party to recruit more "politically progressive" people from the private sector. Jiang said that entrepreneurs, owners of private enterprises, and employees of foreign firms who "make contributions to developing socialism's productive forces and its other endeavors through honest labor and work" should be given a chance to join the party.

The Formation of a Cadre-Capitalist Class: As a result of the above practices, the emerging state-capitalist relation is characterized by the fusion of political capital of the cadres, the economic capital of the capitalists, and the social/network capital embedded in the local society. Many collective enterprises are owned and run by capitalists, while many private enterprises are spined-off state properties owned and run by state managers or their kin. This fusion makes it very hard to distinguish what is owned by the state, by the collective, and by the capitalist in the private sector because the boundaries of their property relations are often blurred.

The fuzzy property boundaries and the mutation between state managers and capitalists have created an all-powerful hybrid which can be called a "cadre-capitalist" class. Goodman (2000) reports that "most entrepreneurs, including those in the private sector of the economy, ..., either had social origins in the party-state or were for the most part incorporated into its activities." Hjellum $(2000$, p.119) reports a survey finding that "[G]enerally speaking, cadres - half government functionaries and half business managers - were at the core of the social networks of entrepreneurs in both cities and towns and rural areas... a good relationship with the government was an important prerequisite for having a satisfying income." This hybrid state-capitalist class has monopolized political capital, economic capital, and social/network capital in the Chinese society. Its members are the beneficiaries of the existing arrangements of partial reforms, mixed economy, and hybrid ownership.

\section{State-Workers Relations}

The Semi-Proletarianization of State Workers: In the pre- 1978 Maoist era, workers in the state sector were guaranteed life-long employment; they controlled their labor process; they enjoyed all sorts of fringe benefits such as health insurance, retirement pensions, housing, nurseries, canteens, bathing facilities; and they provided privileged access to various scarce services, commodities, and essentials of life. As the chief beneficiary of the Maoist policies, workers in the state sector in the pre-reform era did not have an antagonistic relationship with the state.

Nevertheless, due to the need to boost productivity and bring profits into the state sectors in the 1990s, there were attempts to layoff redundant workers, hire temporary and contractual workers, cut wages, reduce workers' benefits, charge workers for services, intensify workloads and to enforce strict work discipline in order to improve the state enterprises' productivity and profitability. As such, workers in the state sector were beginning to feel like they are proletarians working in a capitalist enterprise (Lee, 2000). 
Still, workers in the state sector have not been fully proletarianized. In order to eas: the pain of unemployment for state workers, the state adopted a policy called "off-duty" (xiagang). "Off-duty" workers are those who maintain "employment relations" with th. state enterprises, potentially re-employable if business improves, and who receive live!hood allowances amounting to only a tiny fraction of regular income. Also, "off-duty" workers are still allowed to receive certain fringe benefits like housing, and health services. "Off-duty" workers are entitled to the above arrangements for three years. Only after that will the social security departments of local governments become responsible for the laid-off workers. This "off-duty" scheme has helped to cushion the shock of unemployment and the class antagonism of state workers against the state (Lee, 2000).

Segmented Labor Market and a Divided-Working Class: Even in the private and collective sectors, capitai-labor relations are still mediated through the state. Using the household registration system, the state allows the peasants to leave their farms but not their villages. Thus, the peasants are allowed to work in market towns and urbar cities only as temporary migrant workers. They have no right to settle down permanently in these territories. A new class of temporary migrant workers, many of them yourg women known as dagong mei (maiden workers), has emerged in response to the employment opportunities and an estimated 100 million temporary migrant workers havi ieft the countryside to enter towns and cities in search of non-agricultural jobs.

This state household registration system has created a segmented labor market. Urbanites work as permanent workers in the state sector or in high-paying primary labor markets which provide health care and other benefits. On the other hand, rural temporary migrants can only get jobs in the secondary labor market in the private and collective sectors, and pick up jobs that pay low salary and provide few benefits (Fan, 2000).

Such labor market conditions have led to a divided working class, for it is reinforced by the pattern of residential segregation and ethnic stereotyping. Temporary migrant workers tend to live in very poor quality housing in the urban fringe. Migrant housing generally lacks such facilities as electricity, water supply, drainage and sewage systems, and fire prevention lanes. In addition, temporary migrant workers are regarded as outsiders and are excluded from the local society. Local urban workers have assigned many negative ethnic labels to migrant enclaves, including "paradise of thieves and robbers," "camps for prostitutes," "retreats of hunted criminals," etc. Tensions have been gruwing between urban workers and temporary migrant workers (Taubman, 2000).

\section{State-New Middle Class Relations}

The Expansion and Depoliticization of the New Middle Class: In the pre-1978 Maoist era, the new middle class, especially the intellectual segment, was under the close supervision of the CCP. New middle class intellectuals were the target of attack during the Hundred Flowers Campaign and the Cultural Revolution. In the post-1978 reform era, however, the new middle class is seen as a class that could make significant contributions to economic and political reforms of the Chinese society.

Members of the first generation of the new middle class that emerged in the $1980 \mathrm{~s}$ 
felt that they were special. As victims of the Cultural Revolution, they felt that they had a right to demand reforms. Responding to the US calling of human rights, and encouraged by the liberal-minded leaders in the CCP, the first generation was very active in promoting democracy movements in the 1980s, eventually leading to the explosion of the Tiananmen Incident in 1989.

Nevertheless, members of the second generation of the new middle class that emerged in the 1990s were much less politicized. Although there was only a tiny percentage of students in higher education in the 1980s, this percentage has greatly expanded in the 1990s. University admission rates increased rapidly, with $43 \%$ increase in 1999, and another $20 \%$ increase in 2000 . The rapid expansion of the number of students in higher education has resulted in a rapid expansion of the size of the new middle class. Members of the new middle class are no longer privileged to get access to high-paying jobs, but they have to compete with one another in the professional labor markets. Professional development and career pursuit, not democracy and anti-state politics, became the main concern of college students in the late 1990s (Xue, 2000).

Due to the concentration of power and wealth in the state bureaucracy, many new middle class professionals perceive party membership and bureaucratic employment in the state sector as a good channel for upper mobility. Although they are still critical of the corruption of the state-capitalist class, they have become supporters of the state's reform policies, and will not participate in any open anti-state activity to jeopardize their careers. Instead, they prefer to settle their differences inside the state using existing channels. In the $1990 \mathrm{~s}$, even dissidents in the democracy movement eschewed the tactics of street politics and none of their protests was violent (Mei, 2000).

The Professionalization of Cadres: On the other hand, there is a professionalization of cadres. Before the reform era, cadres in the state bureaucracy were mostly veteran revolutionaries or from peasantry and working class background recruited during the Maoist era. Very few of them have received higher education and a professional degree. However, due to the need to promote economic reforms, the pattern of cadre recruitment has been transformed in the reform era.

Many new middle-level and high-level cadres are professionals because recruitment in the state bureaucracy now favors university degree holders, professional training, and other forms of human capital. Veteran cadres are taking courses in the university because receiving a professional certificate or an academic degree will enhance their chance of promotion in the state bureaucracy. Many cadres are sent to Hong Kong or overseas for short-term training in order to enrich their professional qualification. This professionalization policy, in return, attracts many members of the new middle class to develop their career inside the state sector, resulting in the inbreeding between the new middle class and the cadres.

\section{State-Mediated Class Conflict}

The state not only restructured class relations, but also transformed the pattern of class conflict as well. In the statist society during the Maoist era, political conflict took the 
form of highly intensified rupture conflict. This is because there was no class organization to stand between the state and the individuals, so the state could casily mobilize individuals through political campaigns and the Cultural Revolution. Since 1978, classes and new class relations have emerged, so did new class organizations such as industrial and trading associations, professional associations, independent unions. Together with other civic societies (such as Kung-fu club and religious organizations), these class organizations have begun to act as vehicles to articulate the interests and values for their numbers. As such, will rupture conflict repeat itself in the reform era?

The Superimposition of Class Conflict: As a result of class differentiation and class polarization, class conflict in the post-1978 reform cra has the potential to be intensified, especially different forms of class conflict had superimposed upon one another in the form of attacking the state-capitalist class. State workers blamed the state-capitalist class for laying them off and reducing their benefits. Temporary migrant workers blamed the state-capitalist class for preventing them from settling in the cities and market towns. Peasants blamed the state-capitalist class lor increasing laxes, taking away their land, and imposing a coercive one-child policy. New middle class blamed the state-capitalist class lor their relative decline in living standards and repressive working environnents.

The monopolization of political capital, economic capital, and social/network capital by state-capitalists made this class highly vulnerable to the attacks by other classes. Thus, this state-capitalist class is seen as corrupt, extravagant, morally wrong, abusing its power, exploiting societal resources to enrich itself. Conflict against the state-capitalist class could be highly intense, violent, and took the form of rupture, as epitomized by the popular protests in May and June of 1989.

Corporatism and Institutionalization of Class Conflict: However, having a strong state apparatus, the state-capitalist class still has the capacity to shape the contour of antagonistic class relations, to define the political condition for class formation, and to channel the conflict through the existing institutional framework.

First, the state's policies of "off-duty" workers and household registration helped to dilute the antagonism of the working class as well as create a divided working class. The expansion of higher education, the growing career opportunities in the state bureaucracy, and the professionalization of the cadres have also eased the tension between the new middle class and the state-capitalist class.

Second, in order to prevent new class organizations from challenging its power, the state has adopted the mechanism of corporatism to include them in the state bureaucracy (Francis, 2001). New class organizations - such as The All China Federation of Industry and Commerce and the Private Business Association - are not allowed to form unless they have received the formal endorsement of the state and are included as parts of the state bureaucracy. Also, their leaders, their members, their budgets, and their activities have to get the blessing from the state in order for them to be taken as legitimate organizations in the society. In return for their acceptance of state's authority, these new class organizations are granted privileges to get aceess to state information, state funding, and other forms of state support. Through this practice of corporatism, 
many nascent entrepreneurial associations, labor unions, and professional associations are semi-state organizations rather than autonomous class organizations (Hsiao and So, 1999).

Third, aside from controlling the condition for class formation, the state also tried to channel class conflict into existing institutional channels. In 1987, the State Council revived the national labor dispute arbitration system. By 1997, some 270,000 labor dispute mediation committees had been formed at the enterprise level. In the past decade, enterprise mediation cases amounted to 820,000. In addition, the state has strengthened the National People's Congress, carried out significant legal reforms, and put the village elections in practice. Official data show the National People's Congress issued 222 laws and 84 other pieces of legislation between 1979 and 1998. Of these laws, the most important were the administrative litigation law, the civil procedure law, the revised criminal procedure law, and the new criminal code that came into effect in 1998. With the legal reforms in place, class conflict is increasingly channeled through the legal system instead of through open street protests and armed conflict (Lee, 2000; Mei, 2000).

\section{Consequences on Economic Reforms and Democratization}

Market transition theory argues that economic reforms will create their own dynamics. After marketization is institutionalized, a critical mass of reformers in the state and procapitalist forces in the society will inevitably push for more and more market reforms, a wider opening to the outside world, and the expansion of civil society and democratization. However, this article challenges the prediction of market transition theory, because a state-mediated class-divided society has released different social forces toward economic reforms and democratization.

The formation of a state-mediated class-divided society helps to explain the cyclical nature of reform policies by the Chinese state. Although party leaders have been actively pushing for economic reforms for more than a decade, their reform programs received strong resistance from the state-capitalist class because it wants only partial reform. Fuzzy property boundary and hybrid ownership forms laid the foundation for the fusion of political capital, cconomic capital, and social/network capital. Thus, the state-capitalist class would not want any economic reform that clarifies property boundary and ownership rights. Instead, it has a vested interest to delay or to restrict the scope of the transformation of the mixed economy to a capitalist economy (Zweig, 1999).

Also, if economic reforms (like letting unprofitable state enterprises to go bankrupt, laying off redundant workers, and joining the WTO and increasing the impact of globalization) are pushed ahead with rapid speed, these reforms will transform China from a state-mediated class society toward a class-divided society. If such a path has been adopted and class relations could no longer be mediated by the state, then class conflict will become more intense, eventually threatening the political stability of the present. Due to the risk of political instability, the reformers are still hesitant to push their economic reforms at full speed (So, 1999).

In the political front, it is the state - not the civil society - that is the dominant institution because the state defines the legal channels and the scope of appropriate 
behavior that class forces are allowed to articulate their interests in the state. Of course, class and other civil society organizations can criticize the state and challenge the state's decisions, but they are permitted to do so only through the existing legal channels. Since civil society is absorbed inside the existing legal channels, it would appear that there is little open street protests, public anti-state activities, and violent confrontations between the state and social classes. With such a weak civil society, there is little impetus toward democratic reforms in Chinese society.

\section{Conclusion}

This article discusses the formation of a new state-mediated class-divided society in China. It argues that due to the economic reforms in the post-1978 era, a mixed economy was formed, laying the economic foundation of a class-divided society. Over the past two decades, a capitalist class, an old middle class, and a new middle class have emerged side by side with poor peasantry and urban workers. Like other class-divided society experiencing rapid development, the post- 1978 Chinese society is going through rapid class differentiation, class polarization, and class conflict.

Nevertheless, unlike other class-divided society, the Chinese state has played a decisive role in mediating these class relations, leading to the embourgeoisiement of cadres and the patronization of capitalists, the semi-proletarianization and the segmentation of the working class, the depoliticization of the new middle class, and the professionalization of cadres. Although the fusion of political capital, economic capital, and social/network capital has produced an all-powerful cadre-capitalist class which has become the target of attacks by other classes, the mediation of the state has also led to the incorporation of class organizations into the state bureaucracy and the institutionalization of class conflict.

A state-mediated class-divided society also helps to explain the cyclical trend of reform policies. Economic reforms are strongly resisted by the state-capitalist class which wants to maintain the status quo of partial reform. State leaders are worried that if they have pushed the reforms too far, China would move into a class-divided society, heightening class conflict and threatening the political stability of the communist regime. A state-mediated class-divided society also helps to explain the lack of impetus toward democratization in China. Since class and other civil organizations have been incorporated into the state, they seldom engage in democratic movements to challenge the Chinese communist party.

To what extent is the above class analysis different from the market transition theory and the state-centered theory in the literature? This article is closer to the state-centered theory in its emphasis on the decisive role of the state in mediating the emerging class forces in the reform era. However, different from state-centered theory, this article also highlights the contradiction of a class-divided society. This article shows that although the Chinese state has successfully promoted a robust economic development, it also gave rise to new class relations, growing class conflict, and a state-capitalist class that resist full-blown economic reforms.

How useful is this class analysis in understanding the continuity and transforma- 
tion of the Chinese society in the second half of the twentieth century? Since the literature scldom talks about classes and class conflict, this article hopes that, by bringing classes back in, it will open up new research questions and research frontiers for the study of Chinese stratification and development. For example, while a stratification researcher may look into how the capitalist class, the old middle class, the new middle class, and the working class are differentiated in terms of income, life style, social status, and influence in the community, a class analyst would go further to examine how class differentiation and class polarization are related to class formation, social conflict, and changing state policies in the Chinese society.

As the first attempt to discuss the changing patterns of class relations and class conflict in the post-reform era, this article obviously has raised more questions than provided answers. Many of its crucial terms, like "state-capitalist class," "new middle class," and "segmented working class" need further clarification and operationalization. Many class relations, like that between new middle class and working class, between old middle class and new middle class, and between different segments of the working class need to be further spelled out and specified. Many hypotheses, such as the embourgeoisiement of state managers, the patronization of capitalists, the formation of a state-capitalist class, the semi-proletarianization of the working class, and the depoliticization of new middle class need to be empirically verified. Many important topics, such as class identity, the linkages among class, gender, and ethnicity, the interaction among class formation, class conflict, and state policies demand much more investigation. As the first attempt to examine China social classes, this article has accomplished its task if it could stimulate more discussion and more research on classes and class conflict in Chinese society.

\section{References}

Ding, Xueliang (2000a) "Systemic Irregularity and Spontaneous Property Transformation in the Chinese Financial System," China Quarterly 163.

(2000b) "The Illicit Asset Stripping of Chinese State Firms," The China Journal 43:1-28.

Duckett, Jane (2001) "Bureaucrats in Business, Chinese Style," World Development 29:23-37.

Fan, Cindy (2000) "Migration and the Labor Market in Transitional China," Paper presented to the "International Workshop on Resource Management, Urbanization, and Governance in Hong Kong and the Zhujiang Delta," The Chinese University of Hong Kong, May 23-24, 2000.

Francis, Corinna-barbara (2001) "Quasi-Public, Quasi-Private Trends in Emerging Market Economies," Comparative Politics 33: 275-294.

Goodman, David S.G. (2000) "Centre and Periphery after Twenty Years of Reform: Redefining the Chinese Polity." Paper presented to the conference entitled "Centre-Periphery Relations in China," The Chinese University of Hong Kong, March 24-25, 2000.

(1996) "The People's Republic of China: The Party-State, Capitalist Revolution and New Entrepreneurs." Pp. 225-242 in The New Rich in Asia, edited by Richard Robison and David S.G. Goodman. London: Routledge.

Hjellum, Torstein (2000) "Features of Capitalism and the Restructuring of Ruling Classes in China." Copenhagen Journal of Asian Studies 14: 105-129.

Howell, Jude (1998) "An Unholy Trinity? Civil Society, Economic Liberalization and Democratization in Post-Mao China:" Government and Opposition 33: 56-80.

Hsiao. Michael Hsin-Huang and Alvin Y. So (1999) "Economic Integration and the Transformation of Civil Society in Taiwan, Hong Kong, and South China." Pp. $221-252$ in Imagining China, edited by Shu- 
min Huang and Cheng-Kuang Hsu. Taipei: Institute of Ethnology, Academia Sinica

Huchet, Jean-Francois (2000) "Regional Economies Facing lndustrial Restructuring: Towards New Relationship between Centre and Local Governments?" Paper presented to the conference entitled "Centre-Periphery Relations in China," The Chinese University of Hong Kong, March 24-25, 2000.

Lau, Raymond W.K. (1997) "China: Labour Reform and the Challenge Facing the Working Class." Capital and Class 61: 45-81.

Lee, Ching-Kwan (2000) "Pathways of Labor Insurgency." Pp. $41-61$ in Chinese Societies: Change, Conflict and Resistance, edited by Elizabeth Perry and Mark Selden. London and New York: Routledge. (1998) Gender and the South China Miracle. Berkeley: University of California Press.

Lee, Ming-Kwan (2000) "The Decline of Status in China's Transition from Socialism." Hong Kong Journal of Sociology 1: 53-82.

Nee, Victor (1989) "A Theory of Market Transition." American Sociological Review 54: 663-81.

(1996) "The Emergence of a Market Society: Changing Mechanism of Stratification in China." American Journal of Sociology 101: 908-49.

Parish, William L. and Ethan Michelson (1996) "Politics and Markets: Dual Transformations." American Journal of Sociology 101: 1042-59.

Pearson, Margaret (1998) "China's Emerging Business Class: Democracy”s Harbinger." Current History 97 : 268-272.

Pei, Minxin (2000) "Rights and Resistance: The Changing Context of the Dissident Movement." Pp. 20-40 in Chinese Societies: Change. Conflict, and Resistance, edited by Elizabeth Perry and Mark Selden. London and New York: Routledge.

Perry, Elizabeth and Mark Selden (2000) "Introduction: Reform and Resistence in Contemporary China." Pp. 1-19 in Chinese Societies: Change, Conflict, and Resistance, edited by Elizabeth Perry and Mark Selden. London and New York: Routledge.

Pomfret, John (2001) "China Allows Its Capitalists to Join Party: Communists Recognize Rise of Private Business." Washington Post Foreign Service July 2, 2001, p.A01. "http:// www.washingtonpost com"

Pun, Ngai (2001) "Cultural Construction of Labor Politics: Gender, Kinship, and Ethnicity in a Shenzhen Workplace." Pp. 103-116 in The Chinese Triangle of Mainland-Taiwan-Hong Kong: Comparative and Institutional Analyses, edited by Alvin Y. So, Nan Lin and Dudley Poston. Greenwood Press.

So, Alvin Y. (1999) "China Under the Shadow of the Asian Financial Crisis: Retreat from Economic and Political Liberalism?" Asian Perspectives 23 (\#2): 83-110.

Taubmann, Wolfang (2000) "Urban Administration, Urban Development, and Migrant Enclaves." Paper presented to the "International Workshop on Resource Management, Urbanization, and Governance in Hong Kong and the Zhujiang Delta," The Chinese University of Hong Kong, May 23-24, 2000.

Walder, Andrew (1996) "Markets and Inequalities in Transitional Economies: Toward Testable Theories." American Journal of Sociology 101: 1060-73.

Wang, Shaoguang and Angang Hu (1999) The Political Economy of Uneven Development: The Case of China. Armonk: M.E. Sharpe.

White, Gordon (1976) The Politics of Class and Class Origin: The Case of the Cultural Revolution. Canberra: The Australian National University Press.

Wu, Jieh-Min (2001) "State Policy and Guanxi Network Adaptation in China: Local Bureaucratic RentSeeking." Issues and Studies 37 (\#1): 20-48.

Xue, Lan (2000) "China's Higher Education System in the Age of Globalization and Knowledge Economy." A talk given at the Salzberg Seminar, Austria, June 1-6, 2000.

Zweig, David (1999) "Undemocratic Capitalism: China and the Limits of Economism." The National Interest $56: 63-72$.

(2001) "China's Stalled 'Fifth Wave': Zhu Rongji's Reform Package of 1998-2000." Asian

Survey 41: 231-247. 